\title{
Radar Data for Identifying the Characteristics of Tropical Forest Stands
}

\author{
Agus Wuryanta \\ Balai Penelitian Teknologi Kehutanan Pengelolaan Daerah Aliran Sungai \\ Corresponding author (email: agus_july1065@yahoo.com)
}

\begin{abstract}
Radar is one of remote sensing technology which utilizes active electromagnetic energy and are able to provide information about the characteristics of forest stand. This study utilized JERS-1 (Japanese Earth Resources Satellite-1) and ERS-1 (European Remote Sensing Satellite-1) radar images to analyze the relationship between the radar backscatter value and forest stand characteristics such as Diameter Breast Height (DBH), basal area, and canopy cover. This research was conducted in Jambi Province, Bungo Tebo District, Sumatra, Indonesia. The research site covered the forest concession, Suku Anak Dalam village, the area adjacent to Pelepat and Batang Tebo River, and Kuamang Kuning village. Gamma Map Filter with 7 x 7 window size was applied to reduce speckle noise of the SAR images (ERS-1 and JERS-1). This study found out the positive significant correlation between basal area and DBH with JERS-1 radar backscatter value (i.e., $r=0.75$ and $r=0.70)$, while ERS-1 radar backscatter value has correlation $(r=0.64)$ with the canopy cover.
\end{abstract}

Keyword: Radar, forest stand characteristics, backscatter value.

\begin{abstract}
Abstrak
Radar merupakan salah satu teknologi penginderaan jauh yang menggunakan energi elektromagnetik aktif dan memiliki kemampuan untuk mendapatkan informasi tentang karakteristik tegakan hutan. Penelitian ini menggunakan citra satelit radar JERS-1 (Japanese Earth Resources Satellite-1) dan ERS-1 (European Remote Sensing Satellite-1) untuk menganalisis hubungan timbal balik antara nilai hamburan (backscatter) dan karakteristik tegakan hutan seperti diameter setinggi dada, basal area dan tutupan tajuk. Penelitian dilaksanakan di Provinsi Jambi, Kabupaten Bungo Tebo, Pulau Sumatra, Indonesia. Lokasi penelitian meliputi wilayah Hak Pengusahaan Hutan (HPH), kampung Suku Anak Dalam dan berdekatan dengan sungai Pelepat dan Batang Tebo, serta Desa Kuamang Kuning. Filter Gamma Map dengan ukuran 7 $x 7$ diterapkan pada citra radar (ERS-1 dan JERS-1) untuk mengurangi speckle noise. Hasil penelitian menunjukkan adanya korelasi positifyang signifikan antara basal area yaitu $r=0,75$ dan diameter setinggi dada yaitu $r=0,70$ dengan nilai hamburan (backscatter) pada citra JERS-1, sedangkan nilai hamburan (backscatter) pada citra ERS-1 memiliki korelasi sebesar $r=0,64$ dengan tutupan tajuk.
\end{abstract}

Kata Kunci: Radar, Karakteristik Tegakan Hutan, nilai hamburan.

\section{Introduction}

Indonesia is one among the countries having large tropical forests after Brazil and Zaire. The major part of the Indonesian land surface, i.e., 143 million ha $(75 \%)$ has the status of forest land. However, forests and peatlands in Indonesia is suffering from destructions (Riyanto.2015). Tropical forests are rich in trees and liana, in addition to herbaceous taxa. Wet tropical forest, typically, has more species of herbs (including epiphytes) or shrubs. For the management and surveillance of forest product abundance, information on forest stand characteristics such as Diameter Breast
Height (DBH), basal areal, and canopy cover are required. In fact, the sustainable forest management is an important issue in Indonesia. Forest management cannot be implemented without an understanding on the basic ecology of the forest. One prerequisite for sustainable forest management is reliable information on the dynamics and characteristics of the stands since it is essential to know how the forest will grow and respond to natural condition or occasional disturbances (Riyanto and Wuryanta.2015). Extraction of information on the characteristics of forest stands from remotely sensory data is a fundamental activity 
due to the necessity for a variety of applications including sustainable forest management project. According to international agreement (ITTO. 1991), the obligation of sustainable forest management for timber production must be achieved by the year of 2000. Since 1989, Indonesian Government through the Ministry of Forestry has been doing an inventory of forest by using aerial photo, landsat, and SPOT satellite data (Ministry of Forestry Republic of Indonesia.1993). However, the current methods were evidenced to be inaccurate in acquiring data on annual basis due to the frequent obstacle of severe cloud, fog, and rain. Radar image can be used to overcome the problem. Radar operates in a frequency band of the electromagnetic spectrum known as microwave region. Most radar have been designed for a specific frequency or wavelength in which it is essential to understand the respective attributes of the different wavelengths in order to interpret an image (Trevett., 1986). According to Hord (1986), the advantage of radar remote sensing is due to the wavelength region of radar (between $0.5 \mathrm{~cm}$ and $1 \mathrm{~m}$ ) that results on the capacity to penetrate clouds and smoke, even the wave longer than $2 \mathrm{~cm}$ can penetrate fog and precipitation. Based on Sanden (1990), the capacity of the radar to penetrate the forest canopy, especially the longer wavelength, also include the capability for distinguishing the primary and secondary forest type. While at $\mathrm{X}$-band $(2.75 \mathrm{~cm}$ to $5.21 \mathrm{~cm})$ and C-band $(5.21$ $\mathrm{cm}$ to $7.69 \mathrm{~cm})$, the zonation of vegetation, the identification of deciduous/coniferous forest, and the determination of age/height differences are rated as possible. L-band (19.4 $\mathrm{cm}-76.9 \mathrm{~cm}$ ) appeared to be useful for the differentiation of some broad vegetation classes such as coniferous/deciduous, forest/ non-forest, and flooded/non flooded forest class categorization (Hoekman.1990).

The main objective of this research was to analyze the relationship between the data of ERS-1 and JERS-1 radar backscatter value and the characteristics of forest stands i.e. $\mathrm{DBH}$, basal area, and canopy cover.

\section{Research methods}

\section{Location}

This research was conducted in coordinate between $01^{\circ} 15^{\prime} 00^{\prime \prime}$ to $01^{\circ} 45^{\prime} 00^{\prime \prime}$ South Latitudes and $102^{\circ} 15^{\prime} 00^{\prime \prime}$ to $102^{\circ} 45^{\prime} 00^{\prime \prime}$ East Longitudes. This area lies in Jambi Province, Bungo Tebo District, Sumatra, Indonesia. In addition, the site also covers the area of forest concession, Suku Anak Dalam, Pelepat and Batang Tebo River, and Kuamang Kuning Village. Research location is presented in Fig.1.

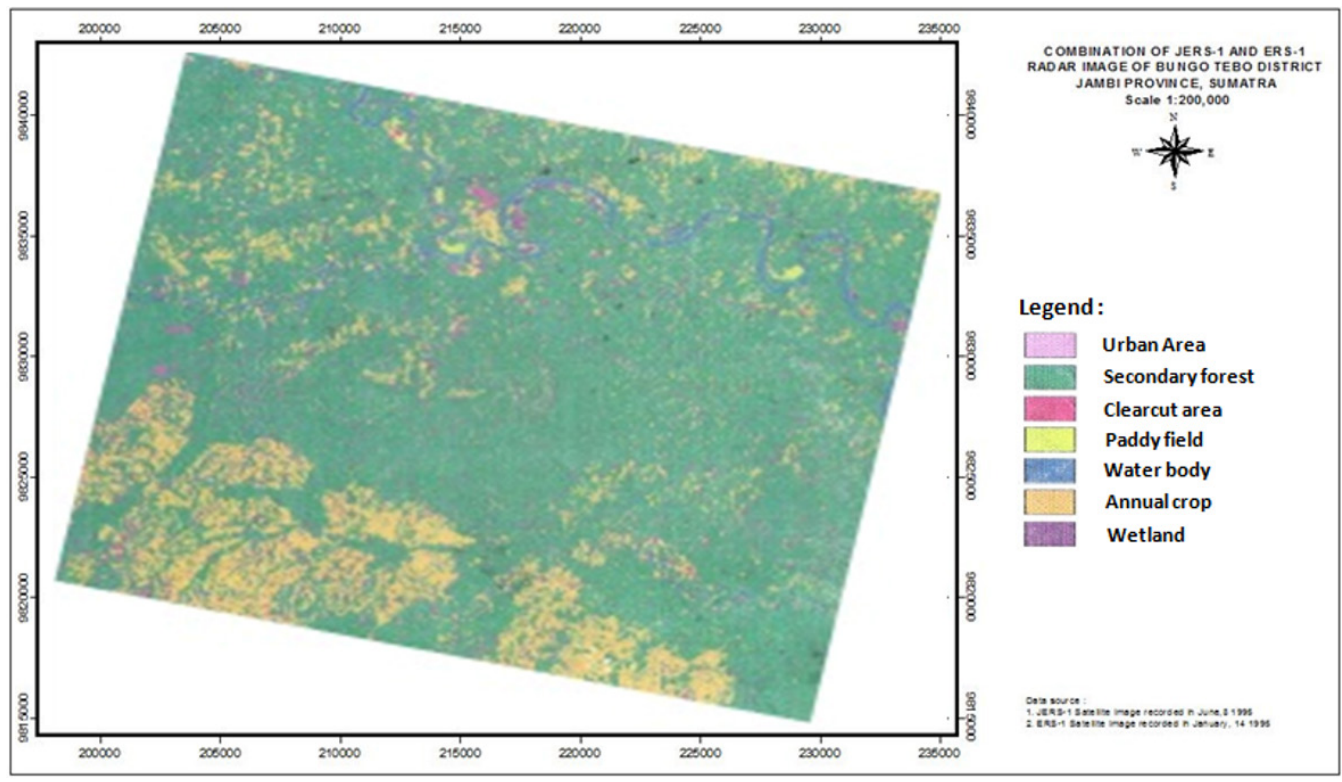

Figure 1. Research location 


\section{Materials and Tools}

The materials used in this research were radar satellite images in digital format, topographic map, and thematic maps. The radar satellite images included the European Remote Sensing satellite-1 (ERS-1) and the Japanese Earth Resources Satellite-1 (JERS-1). ERS-1 satellite operates several sensors, including SAR (Synthetic Aperture Radar) and ATSR (Along-Track Scanning Radiometer), while JERS-1 satellite is land resource satellite which operates radar sensor together with optical sensor (Danoedoro P. 2012). This research utilized multi-temporal ERS-1 radar data obtained on January 14, 1995 (ERS-11), May 04, 1995 (ERS-13), and June 08, 1995 (ERS-15). The first number indicated the generation of the satellite (ERS-1) while the second was intended to differentiate the scenes from one to each other. The characteristics of ERS- 1 and JERS-1 are presented in Table 1.

Table 1. ERS-1 and JERS-1 image characteristics.

\begin{tabular}{lcc}
\hline \multicolumn{1}{c}{ Parameters } & ERS-1 & JERS-1 \\
\hline Frequency & C-band $(5.3 \mathrm{GHz})$ & L-band $(1.2 \mathrm{GHz})$ \\
Wavelength & $5.7 \mathrm{~cm}$ & $23.5 \mathrm{~cm}$ \\
Type & Chirp radar, SAR & SAR \\
Band width & $13.5 \mathrm{MHz}$ & $15 \mathrm{MHz}$ \\
Antenna & Length $10 \mathrm{~m}$, width $1 \mathrm{~m}$ & Length $12 \mathrm{~m}$, width $2.2 \mathrm{~m}$ \\
Polarization & $\mathrm{VV}$ & $\mathrm{HH}$ \\
Angle of Incidence & $23 \mathrm{o}$ & $35 \mathrm{o}$ \\
Height of orbit & $785 \mathrm{~km}$ & $568 \mathrm{~km}$ \\
Track width & $80-100 \mathrm{~km}$ & $75 \mathrm{~km}$ \\
Range resolution & $25 \mathrm{~m}$ & $18 \mathrm{~m}$ \\
Azimuth resolution & $25 \mathrm{~m}$ & $18 \mathrm{~m}(3 \mathrm{looks})$ \\
Recurrent day & 35 days & $44 \mathrm{days}$ \\
\hline
\end{tabular}

Source: https://directory.eoportal.org/web/eoportal/satellite-missions/e/ers-1 (European Remote Sensing Satellite ERS-1) https://directory.eoportal.org/web/ eoportal/satellite-missions/j/jers-1.

There were four topographic maps used in the research area, namely, Lubuk Punggai, Muara Ketato, Muara Kilis, and Muara Tebo. The scale of topographic maps was 1:50,000. While the thematic map used in this research was soil map with a scale of 1:200,000. The tools included digital image processing and GIS analysis such as hardware and software (Erdas Imagine version 9.1 and ArcGIS 9.3). Field survey equipment consisted of compass, Global Positioning System (GPS), ballpoint, and clipboards. Printing equipment consisted of cartridges and papers.

\section{Methods}

According to Lillesand and Keifer (2008), raw digital images usually endure significant geometric distortions that thus they cannot be used as maps. In addition, radar image has unique characteristics in compared with optical image because of its speckle noise. Gamma Map Filter with $7 \times 7$ window size was applied to reduce speckle noise of the SAR images (ERS-1 and JERS-1). Geometric correction converted a raster image after filtering as slave to a topographic map reference in a metric as master. Clearly identifiable points on both the slave and master map were selected for tiepoints. Affine transformation was applied to transform the image. Selection of sample plots was done using simple random sampling method. Coordinates of the plot (known as centre of the plot) were then obtained from Landsat Thematic Mapper (TM) image and topographic map. Sample plots were collected during field work activities. To ensure each centre of the plot, the coordinates were measured using Global Positioning System 
(GPS). After the centre of the plot was determined, a circular plot was measured out with a radius that would lead to a total area of $500 \mathrm{~m}^{2}$. The radius would be in the range of approximately $12.62 \mathrm{~m}$ to $12.70 \mathrm{~m}$. Total number of sample plots were 58 sample plots: 45 sample plots on forest area and 13 sample plots on rubber plantation.

\section{Results and Discussion}

Measurement and recording of plot parameters

Plot parameters were measured and recorded on a prepared tally sheet. There were 86 sample plots in which 58 sample plots were used in this research. The parameters included the coordinates of the plot centre, slope, aspect, canopy cover, undergrowth cover and landuse. In case of the plot was on a forest or rubber plantation, measurement of Diameter at Breast Height (DBH) greater than $10 \mathrm{~cm}$ was done in each tree. From the dbh measurements, the number of tree in the plot was recorded. The average tree height was also estimated. The result of measurement and recording of plot parameters is presented in table 2.

Table 2. Sample plots coordinate and recording of plot parameters

\begin{tabular}{|c|c|c|c|c|c|c|c|c|c|c|c|c|}
\hline \multirow[t]{2}{*}{ No } & \multicolumn{2}{|c|}{ Coordinate } & \multicolumn{4}{|c|}{ Backscatter value } & \multicolumn{4}{|c|}{ Forest stand characteristics } & \multirow[t]{2}{*}{ N.Trees } & \multirow[t]{2}{*}{ Landuse } \\
\hline & $\mathbf{X}$ & $\mathbf{Y}$ & $\begin{array}{c}\text { JERS- } \\
1\end{array}$ & $\begin{array}{c}\text { ERS- } \\
11\end{array}$ & $\begin{array}{c}\text { ERS- } \\
13\end{array}$ & $\begin{array}{c}\text { ERS- } \\
15\end{array}$ & C.cov & A.DBH & BA/ha & A.Heigh & & \\
\hline 1 & 207545 & 9827341 & 127.3 & 136.6 & 104.4 & 120.5 & 70 & 18.7 & 12.1 & 20 & 22 & Forest \\
\hline 2 & 203272 & 9821311 & 86.5 & 108.7 & 110.4 & 99.7 & 50 & 13.7 & 1.76 & 11 & 6 & forest \\
\hline 3 & 204634 & 9828743 & 140.3 & 132.3 & 89.2 & 105.9 & 70 & 18.9 & 14.5 & 21 & 26 & Forest \\
\hline 4 & 232943 & 9838299 & 131.8 & 125.6 & 132 & 102.6 & 65 & 19.9 & 14.3 & 23 & 23 & Forest \\
\hline 5 & 195126 & 9835824 & 115 & 112.3 & 105.5 & 104 & 65 & 16 & 8.08 & 21 & 20 & Forest \\
\hline 6 & 213941 & 9838089 & 109.2 & 124 & 108 & 103 & 30 & 14.8 & 4.48 & 15 & 13 & Forest \\
\hline 7 & 227824 & 9837083 & 167.3 & 120 & 137.9 & 117.3 & 40 & 24 & 11.7 & 16 & 14 & Forest \\
\hline 8 & 208992 & 9818003 & 155.3 & 135.8 & 130 & 110.4 & 20 & 26 & 14.7 & 15 & 5 & Forest \\
\hline 9 & 201233 & 9829391 & 155.6 & 137.4 & 122.8 & 136.3 & 75 & 20.2 & 17.9 & 22 & 15 & Forest \\
\hline 10 & 209610 & 9819390 & 158.7 & 142.1 & 124.8 & 141.2 & 80 & 24.7 & 22.5 & 24 & 28 & Forest \\
\hline 11 & 226390 & 9825521 & 150.4 & 122 & 122 & 137 & 70 & 20.4 & 21.5 & 23 & 24 & Forest \\
\hline 12 & 224386 & 9825448 & 115.2 & 120.7 & 105 & 86.4 & 65 & 11.8 & 2.62 & 15 & 33 & Forest \\
\hline 13 & 216265 & 9830382 & 133.7 & 132.4 & 131.9 & 112.4 & 70 & 20 & 17.8 & 14 & 12 & Forest \\
\hline 14 & 212086 & 9823983 & 142 & 131 & 122.6 & 117.4 & 75 & 16 & 11.2 & 12 & 30 & Forest \\
\hline 15 & 226715 & 9830370 & 134 & 136.1 & 102.4 & 111.9 & 80 & 18.3 & 14.8 & 13 & 41 & Forest \\
\hline 16 & 219966 & 9822106 & 144.4 & 199.9 & 118.9 & 109 & 60 & 18.8 & 15.8 & 16 & 28 & Forest \\
\hline 17 & 222041 & 9823606 & 117.4 & 126.9 & 127 & 121.2 & 75 & 18 & 13.8 & 25 & 28 & Forest \\
\hline 18 & 222364 & 9821198 & 129.2 & 138.1 & 134.6 & 121.9 & 80 & 23 & 15 & 23 & 29 & Forest \\
\hline 19 & 226053 & 9838920 & 125.2 & 111.3 & 101.1 & 107.6 & 60 & 17.4 & 8.32 & 25 & 27 & Forest \\
\hline 20 & 222281 & 9821421 & 135.6 & 107.4 & 157 & 114.3 & 65 & 18.3 & 18.3 & 26 & 18 & forest \\
\hline 21 & 226967 & 9816050 & 127.4 & 105.8 & 125.4 & 107.1 & 10 & 14.5 & 9.91 & 8 & 7 & Forest \\
\hline 22 & 207749 & 9830280 & 160.2 & 166.1 & 140.4 & 155.4 & 80 & 35 & 23.3 & 20 & 35 & Forest \\
\hline 23 & 209050 & 9837905 & 134.7 & 102.1 & 103.9 & 102.1 & 55 & 22.9 & 18.2 & 17 & 30 & forest \\
\hline 24 & 205002 & 9828035 & 138.3 & 119.7 & 170.6 & 122.1 & 55 & 20.7 & 16.9 & 25 & 12 & forest \\
\hline 25 & 211899 & 9821934 & 136.9 & 118.8 & 129.6 & 148.7 & 55 & 21.3 & 15.6 & 21 & 22 & forest \\
\hline 26 & 228052 & 9825336 & 112.1 & 112.1 & 121 & 122.8 & 65 & 17.7 & 7.41 & 18 & 25 & Forest \\
\hline 27 & 227002 & 9830520 & 110.5 & 100.9 & 116.4 & 120 & 60 & 12.7 & 5.56 & 25 & 22 & Forest \\
\hline
\end{tabular}




\begin{tabular}{|c|c|c|c|c|c|c|c|c|c|c|c|c|}
\hline 28 & 205134 & 9836995 & 114.5 & 103.5 & 101.6 & 104.2 & 60 & 22 & 9.18 & 20 & 28 & Forest \\
\hline 29 & 213746 & 9830350 & 119 & 120.1 & 104.9 & 113.2 & 75 & 18.1 & 8 & 20 & 15 & Forest \\
\hline 30 & 200054 & 9814156 & 104.2 & 98.7 & 100 & 98.9 & 45 & 11 & 3.22 & 5 & 22 & Rubber \\
\hline 31 & 218488 & 9840146 & 118.9 & 125.2 & 114.9 & 135.3 & 65 & 18 & 13.2 & 15 & 11 & Rubber \\
\hline 32 & 211274 & 9826970 & 105.4 & 144.8 & 124.2 & 145.7 & 75 & 16.3 & 6.24 & 20 & 14 & Rubber \\
\hline 33 & 200639 & 9816079 & 144.8 & 114.3 & 139.2 & 104.1 & 60 & 27.5 & 13.8 & 12 & 16 & Rubber \\
\hline 3 & 202304 & 9841531 & 132.2 & 104 & 102 & 105 & 40 & 20.1 & 9.55 & 18 & 26 & Rubber \\
\hline 35 & 226013 & 9818042 & 98.2 & 110.8 & 112.3 & 100.6 & 50 & 15 & 2.12 & 11 & 15 & Rubber \\
\hline 36 & 236428 & 9828502 & 131.2 & 121.3 & 116 & 118.7 & 35 & 26 & 5.43 & 16 & 11 & Rubber \\
\hline 3 & 200997 & 9843102 & 132.4 & 105.6 & 107.2 & 105.6 & 20 & 14.9 & 9.77 & 15 & 15 & Rubber \\
\hline 38 & 200677 & 9841873 & 125.6 & 115.8 & 117.8 & 103.2 & 30 & 18.1 & 11.3 & 12 & 6 & Rubber \\
\hline 3 & 203981 & 9837116 & 152.2 & 125.9 & 120.2 & 128.1 & 40 & 20.1 & 17.9 & 20 & 5 & Rubber \\
\hline 40 & 232266 & 9821369 & 135.2 & 143.2 & 112.3 & 109.6 & 45 & 22.5 & 14.3 & 15 & 28 & Rubber \\
\hline 41 & 228885 & 9818257 & 102.8 & 107 & 100.8 & 100.8 & 30 & 5.8 & 8 & 17 & 22 & Rubber \\
\hline 42 & 215684 & 9827257 & 166.7 & 162.9 & 115.8 & 133.2 & 75 & 30 & 20.7 & 15 & 28 & Rubber \\
\hline 43 & 212535 & 9830307 & 155.8 & 146.7 & 112.4 & 143.1 & 70 & 16.2 & 17.3 & 30 & 20 & Forest \\
\hline 4 & 212135 & 9830307 & 122.6 & 148.7 & 115.4 & 100.9 & 75 & 18.5 & 18.7 & 9 & 21 & Forest \\
\hline 45 & 225525 & 9830307 & 129.2 & 103.9 & 107.5 & 98 & 30 & 19.1 & 10 & 18 & 21 & Forest \\
\hline 4 & 224980 & 9830300 & 130.5 & 142.9 & 136.1 & 132.1 & 60 & 19.6 & 12 & 23 & 20 & Forest \\
\hline 47 & 213397 & 9830244 & 125.4 & 151.8 & 149.3 & 143.8 & 70 & 20.5 & 19.3 & 20 & 20 & Forest \\
\hline 48 & 213083 & 9830200 & 129.9 & 125.4 & 123 & 96.2 & 75 & 21.5 & 14.7 & 23 & 20 & Forest \\
\hline 49 & 213946 & 9830350 & 153.7 & 92.3 & 105.1 & 124.6 & 50 & 30.4 & 22.7 & 20 & 20 & Forest \\
\hline 50 & 227123 & 9830383 & 118.1 & 132.8 & 129.8 & 98.4 & 55 & 16.6 & 9.34 & 20 & 20 & Forest \\
\hline 51 & 227064 & 9830412 & 120.4 & 120.2 & 119.7 & 114 & 70 & 23.4 & 10.7 & 25 & 20 & Forest \\
\hline 52 & 232155 & 9830421 & 110.2 & 133.6 & 125.3 & 117.8 & 60 & 12.8 & 10 & 25 & 20 & Forest \\
\hline 53 & 230330 & 9830819 & 125.5 & 141.3 & 126.8 & 147 & 80 & 24.4 & 10.7 & 22 & 20 & Forest \\
\hline 54 & 228200 & 9830924 & 104.2 & 107.4 & 104 & 114.3 & 60 & 15 & 9 & 20 & 20 & Forest \\
\hline 55 & 233515 & 9830400 & 119.8 & 125 & 127.3 & 104.1 & 60 & 16.8 & 16.1 & 15 & 20 & Forest \\
\hline 56 & 234060 & 9830400 & 118.4 & 125.6 & 110.4 & 108.3 & 70 & 15.2 & 14.3 & 20 & 20 & Forest \\
\hline 57 & 237960 & 9830470 & 117.3 & 98.7 & 100.1 & 91.4 & 40 & 15.2 & 6 & 15 & 20 & Forest \\
\hline 58 & 207749 & 9830280 & 123.5 & 133.4 & 129.7 & 124.7 & 75 & 21.9 & 18.8 & 15 & 20 & Forest \\
\hline
\end{tabular}

The Relationship Between Radar average DBH (i.e., $r=0.7)$. Height of trees had Backscatter and Forest Stand insignificant correlation (i.e., $r=0.21$ ) with Characteristics in association with the JERS-1 radar backscatter. Canopy cover also Function of Wavelength, Incidence Angle, showed insignificant correlation (i.e., $r=0.25$ ) and Polarization

The influence of the wavelength on the radar backscatter is related to the capability of the radar energy in penetrating the forest canopy. Longer wavelengths, such as L -band (23.5 $\mathrm{cm})$, have higher ability to penetrate the forest canopy than C-band $(5.7 \mathrm{~cm})$. C-band has low penetration capability and the signal is reflected mainly by the canopy of the forest. JERS-1 image showed a good positive correlation (i.e., $r=0.75$ ) with basal area and with JERS-1 radar backscatter, indicating that longer wavelength such as L-band had significant relationship with forest stand characteristics such as DBH and basal area. ERS-1 with C-band radar backscatter showed insignificant correlation with forest stand characteristics, except with canopy cover. There was a considerable positive relationship between radar backscatter of ERS-11 image (i.e., $r=0.64$ ) with canopy cover. While there was insignificant correlation (i.e., $r=0.22$ ) 
between ERS-13 and canopy cover, moreover ERS-15 had positive correlation $(r=0.48)$ with canopy cover.

Polarization describes the orientation of the electric field component of an electromagnetic wave. There are two types of polarization, namely, like polarization and cross polarization. JERS -1 was using VV polarization while ERS-1 was using $\mathrm{HH}$ polarization. $\mathrm{HH}$ polarization means that the antenna of radar sends and received the signal in horizontal mode, while VV polarization means that the antenna of radar sends and received the signal in vertical mode. Different polarizations will influence the obtained information of the image. For instance, polarized data provides more information on the images especially information on forest structure under the forest canopy as the result of the ground-trunk interactions (Hoekman,1990).

\section{Estimation of Forest Stand Characteristics Using Radar Backscatter}

Data of forest stand characteristics in this study was collected from the natural forest with the method of sampling technique. Regression analysis was performed on the DBH, canopy cover, basal area, and average height with the radar backscatter of ERS-1 and JERS-1 images. Regression equations of the relationship between radar backscatter and the forest stand characteristics are presented on Table 3. Based on Table 3, JERS-1 radar backscatter has positive correlation with basal area and $\mathrm{DBH}$, it means that basal area and DBH can be estimated by using JERS-1 radar image. Correlation between basal area and backscatter value of JERS-1 radar image is presented in Fig.2. While Fig. 3. shows the correlation between average $\mathrm{DBH}$ and backscatter value of JERS-1 radar image.

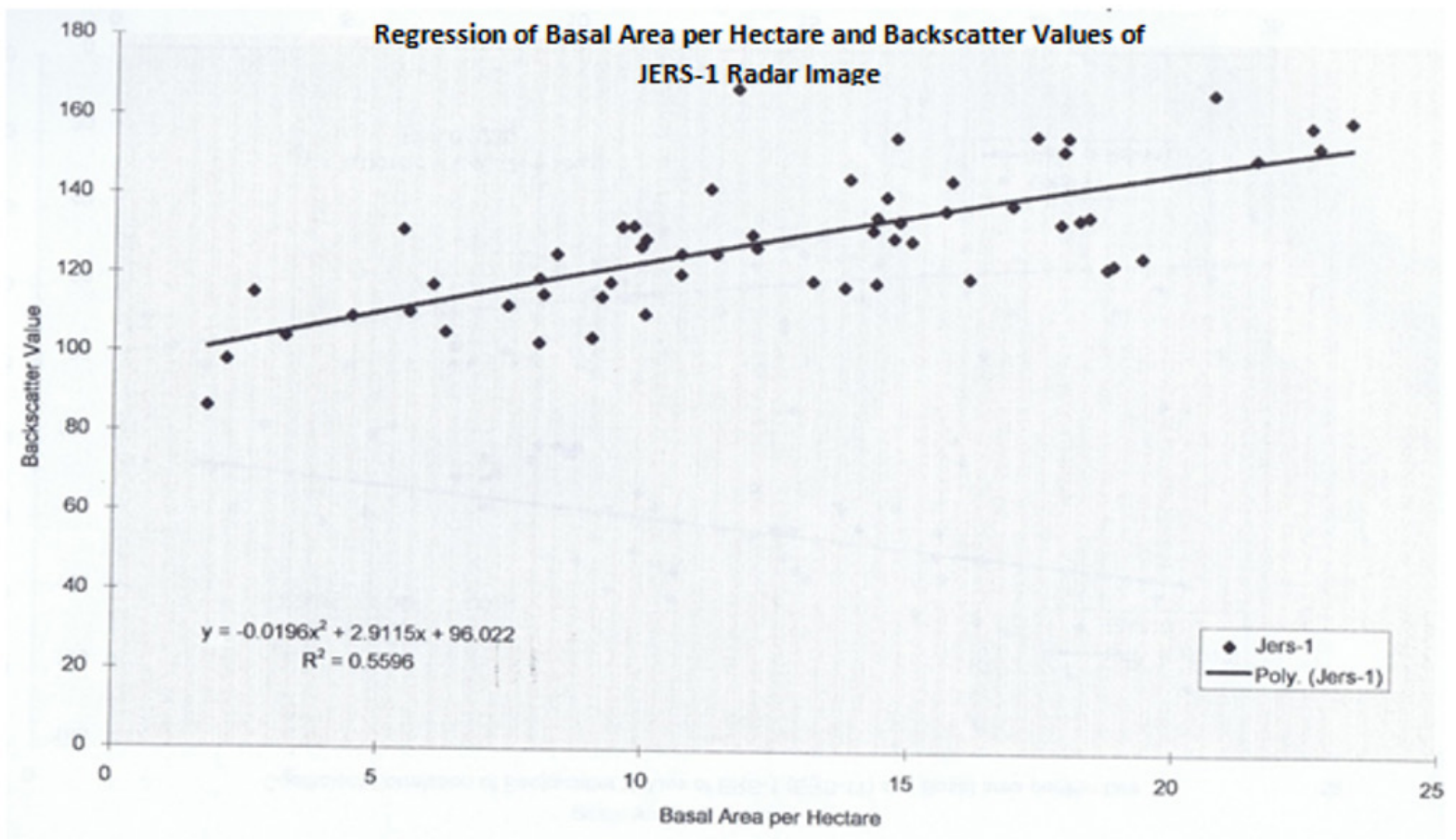

Figure 2. The correlation between Basal Area per Hectare and JERS-1 Radar Backscatter value 


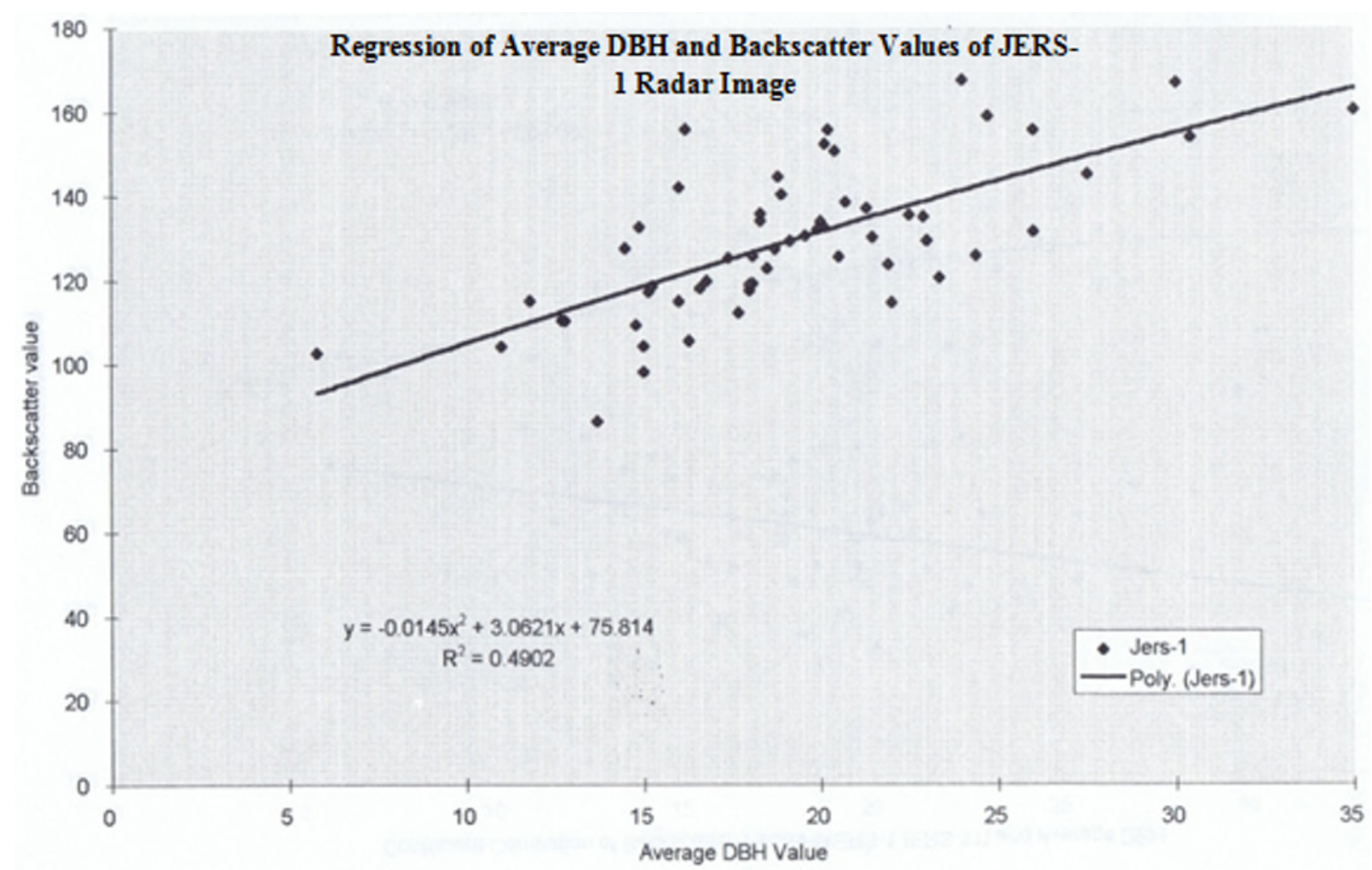

Figure 3. The correlation between Average DBH and JERS-1. Radar Backscatter value

Table 3. Correlation model between radar backscatter of ERS-1 and JERS-1 with forest stand characteristics.

\begin{tabular}{lcccc}
\hline \multicolumn{1}{c}{ Parameters } & JERS-1 & ERS-11 & ERS-13 & ERS-15 \\
\hline \multirow{2}{*}{ Canopy cover } & $\mathrm{Y}=0.0123 \mathrm{x} 2-$ & $\mathrm{Y}=0.017 \mathrm{x} 2-$ & $\mathrm{Y}=0.004 \mathrm{x} 2-0.25 \mathrm{x}$ & $\mathrm{Y}=0.01 \mathrm{x} 2-064 \mathrm{x}+$ \\
& $1.15 \mathrm{x}+150.71$ & $1.29 \mathrm{x}+133.8$ & +118.89 & 115.67 \\
DBH & $\mathrm{Y}=-0.014 \mathrm{x} 2+$ & $\mathrm{Y}=0.001 \mathrm{x} 2+1.24 \mathrm{x}$ & $\mathrm{Y}=-0.043 \mathrm{x} 2+$ & $\mathrm{Y}=0.0125 \mathrm{x} 2+$ \\
& $3.06 \mathrm{x}+75.81$ & +99.69 & $2.81 \mathrm{x}+82.021$ & $0.92 \mathrm{x}+93.27$ \\
Average Height & $\mathrm{Y}=-0.043 \mathrm{x} 2+$ & $\mathrm{Y}=-0.027 \mathrm{x} 2+$ & $\mathrm{Y}=0.037 \mathrm{x} 2-0.55 \mathrm{x}$ & $\mathrm{Y}=-0.001 \mathrm{x} 2+$ \\
& $2.23 \mathrm{x}+103.84$ & $1.49 \mathrm{x}+105.98$ & +115.79 & $1.55 \mathrm{x}+89.24$ \\
Basal Area & $\mathrm{Y}=-0.019 \mathrm{x} 2+$ & $\mathrm{Y}=-0.001 \mathrm{x} 2+$ & $\mathrm{Y}=-0.034 \mathrm{x} 2+$ & $\mathrm{Y}=0.057 \mathrm{x} 2+$ \\
& $2.91 \mathrm{x}+96.02$ & $1.46 \mathrm{x}+105.61$ & $2.03 \mathrm{x}+100.01$ & $0.056 \mathrm{x}+104.44$ \\
\hline
\end{tabular}

\section{Conclusions}

1. JERS-1 radar backscatter values had significant correlation (i.e., $r=0.75$ ) with basal area per hectare and average DBH (r $=0.7$ ). Height of trees and canopy cover had insignificant correlation with JERS-1 radar backscatter values.

2. ERS-1 radar backscatter values had insignificant correlation with forest stand characteristics such as average $\mathrm{DBH}$, basal area, and average height

3. This study found the best regression equations that can be applied to estimate basal area and average DBH was developed from radar backscatter values of JERS-1 image.
4. Forest stand characteristics such as basal area and average DBH can be estimated by using JERS-1 radar image.

\section{Recommendations}

1. Despite the excellence of remote sensory images, it is advisable to have a prior knowledge of the study area such as crop calendar and other indigenous practices that may affect the land use to obtain the optimal result.

2. Remote sensing radar can be used in all weather conditions, particularly for forest monitoring project, but it still has some obstacles including a). Radar imagery system has totally different physically 
and geometrically principles in compared with the optical systems b). The general lack of understanding on microwave interaction with vegetated terrain.

3. For some regions that are covered by clouds, rain and fog permanently, radar satellite imagery can be used as a substitute of optical images for forest monitoring and inventory

\section{Acknowledgement}

I would like to express my sincere gratitude and thank to Mr. Reinink staff of IPL, ITC The Netherlands who guide me during the image processing activity. Also for Sam, Hamid, and Belinda for the collaboration in collecting the data and discussion during the data processing.

\section{References}

Danoedoro P. 2012. Pengantar Penginderaan Jauh Digital. Andi. Yogyakarta

ERDAS Inc. 1999. ERDAS Field Guide, ERDAS Worldwide Headquarters, Atlanta, Georgia.

Hord Michael R. 1986. Remote Sensing. Methods and Applications. John Wiley \& Sons. Inc. Canada.

Hoekman, D.H. 1990. Radar Remote Sensing Data for Applications in Forestry. Ph.D Thesis, Wageningen Agricultural University, The Netherlands.

ITTO. 1991. Sustainable Management of Tropical Forest. Criteria for Sustainability. Yokohama, Eleventh session.

Lillesand, T. M. and R. W. Kiefer. 2008. Remote sensing and image interpretation, John Wiley \& Sons, Inc

Ministry of Forestry Republic of Indonesia. 1993. Tropical Forests of Indonesia. A Country Paper.

Riyanto, Ahmad E. 2015. Mapping Social and Economic Vulnerability in Forest and Peatland Fire Disaster in Bengkalis, Riau Province. Forum Geografi, Vol.29 (1) July 2015:41-48.

Riyanto, H D and Wuryanta, A. 2015. Study on Species Diversity and Stand Structure in Meru Betiri National Park. Forum Geografi, Vol.29 (1) July 2015. Pp. 73-82.

Sanden Van Der., J.J. 1990. Radar Remote Sensing of Tropical Forest: A Literature Review. BCRS Project, AO-2.22 Wageningen The Netherlands.

Trevett, J.W. 1986. Imaging Radar for Resources Surveys. Chapman and Hall Ltd.

https://directory.eoportal.org/web/eoportal/satellite-missions/j/jers-1.January 12 2016.JERS-1 (Japan Earth Resources Satellite)/Fuyo-1.

https://directory.eoportal.org/web/eoportal/satellite-missions/e/ers-1.January $12 \quad 2016$. European Remote Sensing Satellite ERS-1. 